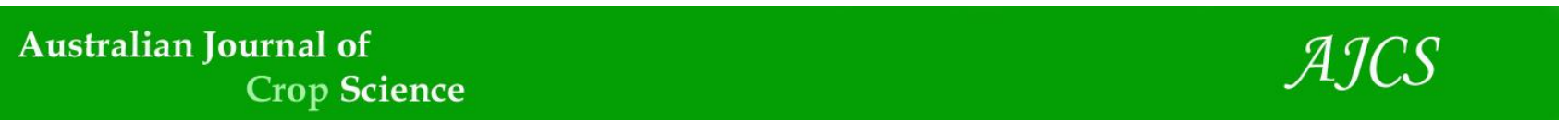

AJCS 14(09):1473-1478 (2020)

ISSN:1835-2707

doi: 10.21475/ajcs.20.14.09.p2558

\title{
Pretreatment of maize seeds with different magnesium nanoparticles improves the germinating performance and storability
}

\section{Cristiane SEGATTO ${ }^{1}$, Clovis Arruda SOUZA ${ }^{1 *}$, Cristiano Reschke LAJÚs ${ }^{2}$, Márcio Antônio FIORI ${ }^{2}$, Luciano Luiz SILVA ${ }^{2}$, Humberto Gracher RIELLA ${ }^{3}$, Cileide Maria Medeiros COELHO ${ }^{1}$}

\author{
${ }^{1}$ Santa Catarina State University, Agronomy Department, Crop Plant Laboratory, Lages, Santa Catarina, Brazil \\ ${ }^{2}$ Universidade Comunitária da Região de Chapecó, Chapecó, Santa Catarina, Brazil \\ ${ }^{3}$ Federal University of Santa Catarina, Faculty of Chemical Engineering, Florianópolis, Santa Catarina, Brazil
}

*Corresponding author: souza_clovis@yahoo.com.br

\begin{abstract}
The objective of this study was to evaluate the effect of treatment with simple or coated nanoparticle and concentrations on storage time and the germination parameters in corn seeds. The treatments composed of three magnesium sources, magnesium oxide nanoparticles and nanoparticles in the form of (MgO NPs), magnesium carbon oxide core-shell nanoparticles (MgO@C NPs) and magnesium nitrate $\left[\mathrm{Mg}\left(\mathrm{NO}_{3}\right)_{2}\right]$. Six concentrations 0 (control) 37.5, 75, 150, 300 and $600 \mathrm{mg}^{-1} \mathrm{~L}^{-1}$ were applied. The treated seeds were submitted to germination tests, after different storage times: 0, 30, 60, 90 and 150 days and then the normal and abnormal seedlings were evaluated. The results indicate that the treatment process with simple or coated nanoparticles with optimal concentration value, between 75 and $150 \mathrm{mg} . \mathrm{L}^{-1}$ of $\mathrm{Mg}$, can approximately increase $6 \%$ of normal seedlings in conjunction with the storage time (90-150 days). The exposure of the seeds to magnesium nitrate resulted in less normal plants, possibly due to the saline and toxic effect of this source. The best germination performance of seeds pretreated with simple or coated nanoparticles can be achieved at the concentration of $75 \mathrm{mg} \cdot \mathrm{L}^{-1}$ and for the storage time of 150 days. There might be some negative effect for magnesium nitrate depending on concentration and storage time.
\end{abstract}

Keywords: Core-shell; Germination; Macronutrient; Nanotechnology; Zea mays.

Abbreviations: Mg_magnesium; MgO NP_magnesium oxide nanoparticles; MgO@C NPs_magnesium carbon oxide core-shell nanoparticles; $\mathrm{Mg}\left(\mathrm{NO}_{3}\right)_{2}$ magnesium nitrate; $\mathrm{FAO}$ _Food and Agriculture Organization of the United Nations; CQFS RS/SC_Comissão de Química e Fertilidade do Solo dos Estados do Rio Grande do Sul e Santa Catarina; UNOCHAPECÓ_Universidade Comunitária de Região de Chapecó.

\section{Introduction}

Technological innovations were developed for maize cultivation in recent years are largely directed towards reducing production costs associated with increased grain yield. In Brazil's agricultural matrix, maize production was increased in the last decade (2007 to 2017) from 52.1 to 97.7 million tons (FAO, 2019). This fact added a great economic importance to this crop for the country and increased its worldwide visibility. This increase in production was only obtained through the use of agricultural inputs, including mineral fertilizers.

Many studies have devoted special attention to improve techniques for the soil macronutrient availability. This availability is one of the strategies to increase grain yield. In particular, magnesium availability processes for maize plants have adopted procedures that employ the direct application of magnesium precursor compounds to the soil, the most common being dolomitic limestone or magnesian limestone (CQFS RS/SC, 2016). Using these methods, much of the magnesium intended for agricultural crops is not made available via seeds, because the areas used for agricultural cultivation require periodic liming procedures, which in many cases are not efficient. Magnesium $(\mathrm{Mg})$ is an essential macronutrient for plant growth and development (Gransee and Führs, 2013). Mg is essential for the plant photosynthesis, since 15 to $35 \%$ of the total $\mathrm{Mg}$ in plants is bound to chloroplasts, mainly as a constituent of chlorophyll, where $\mathrm{Mg}$ is a key component in the energy transfer process (Cakmak and Yazici, 2010). In addition, a considerable proportion of $\mathrm{Mg}$ in plant cells is used as a binding element for ribosome aggregation and thus play a key role in protein synthesis (Gout et al., 2014).

Despite the technological information accumulated by the agronomic sector, nanotechnology is on the rise due to showing promising results in the control of the excessive use of agricultural inputs and in maintaining the environmental balance (Chhipa, 2019). Recent studies indicate that the treatment of maize seeds with nanoparticles of zinc oxide and magnesium oxide provides synergistic gains in seed and plant protection from germination to vegetative stage and with potential increase for grain yield due to the nanoparticle antimicrobial activity (Wani and Shah, 2012; Segatto et al., 2018).

Nanotechnology is advancing and providing technological changes in agronomy (Aguar-Fernandez and Hullmann, 2007). In the agricultural and food industry, advances in nanotechnology have provided new tools for the molecular 
management of diseases and for increasing the ability of plants to absorb nutrients, resulting in increased grain yield and also the nutritional value of grains (Tarafdar et al., 2013). However, the effects of nanoparticles on plants are still poorly known and may vary positively or negatively, depending on factors such as plant species, via of incorporation (seed, root or leaf), chemical element and chemical composition, and concentration of nanoparticles (Liu et al., 2016).

In turn, few studies have evaluated the effects of magnesium oxide nanoparticles on seed treatment and their effects on emergence and grain yield, especially in annual crops such as maize. The objective of this research was to evaluate the effects of seed treatment with nanoparticles (magnesium oxide or core magnesium-oxide-shell) and magnesium nitrate at different concentrations associated with storage time on maize seed germination.

\section{Results}

\section{Interaction Mg source per storage time}

The analysis of variance indicated a significant effect $(P \leq 0.05)$ on the storage time of pretreated seeds containing concentrations of magnesium oxide nanoparticles (MgO NPs), magnesium carbon oxide core-shell nanoparticles (MgO@C NPs) and magnesium nitrate $\left[\mathrm{Mg}\left(\mathrm{NO}_{3}\right)_{2}\right]$, for the percentage of normal and abnormal seedlings.

A negative effect was observed, particularly for the $\mathrm{Mg}\left(\mathrm{NO}_{3}\right)_{2}$ source, which significantly reduced germination by $6 \%$ compared to the control or seeds treated with MgO NPs and by up to $11.6 \%$ reduction, compared to the MgO@C NPs treatment. Even occurring this negative effect, the germination percentage was higher than the established for commercialization (minimum of $85 \%$ ) (Brasil, 2013).

During storage of pretreated seeds with $\mathrm{Mg}\left(\mathrm{NO}_{3}\right)_{2}$, the percentage of abnormal seedlings from 30 to 150 days of storage increased from 8 to $14 \%$, respectively (Fig. 1). On the other hand, the germination percentage was decreased from $92 \%$ to $86 \%$, respectively. No changes were observed in the percentage of dead seeds, which was around $1 \%$ (data not shown). Seeds treated with MgO NPs and MgO@C NPs showed a constant behavior in relation to abnormal seedlings, during all storage times as shown in Fig. 1.

Up to 60 days of seed storage, a clear source effect was observed, particularly in $\mathrm{Mg}\left(\mathrm{NO}_{3}\right)_{2}$. It had a negative effect on the germination performance of maize seeds, while both sources of nanoparticles preserved the seed germinability or even provided some benefit to these seeds over the storage time (Fig. 1) maintaining germination around 95\% during storage of 150 days.

\section{Interaction of $\mathrm{Mg}$ source $\times \mathrm{Mg}$ concentrations into storage time}

The unfolding of interactions sources of $M g$ source $x$ concentrations in each storage times are shown in Fig. 2. Independent of the source [MgO NPs, MgO@C NPs or $\left.\mathrm{Mg}\left(\mathrm{NO}_{3}\right)_{2}\right]$, at zero day of storage, the analysis of variance revealed a significant effect $(P \leq 0.05)$ on germination percentage or decreasing number of abnormal seedlings (Fig. 2a ). These data are pointing to a beneficial but low effect of $\mathrm{Mg}$ on germination percentage, with respective decreasing number of abnormal seedlings.

At 30th days of pretreated seeds storage, the percentage of seed germination and abnormal seedlings showed a little effect on Mg source as function of Mg concentrations in the average of the three sources [MgO NPs, MgO@C NPs and $\mathrm{Mg}(\mathrm{NO} 3)_{2}$ ]. Particularly, the magnesium nitrate source $\left[\mathrm{Mg}\left(\mathrm{NO}_{3}\right)_{2}\right]$ germination decreased from 92 to $88 \%$ and from 37.5 to $600 \mathrm{mg} \cdot \mathrm{L}^{-1}$, respectively, while the other Mg NPs sources showed plateau about $96 \%$ of germination from concentrations of 75 to $600 \mathrm{mg} \cdot \mathrm{L}^{-1}$.

At 60th, 90th and 150th days of storage after pretreatment, the analysis of variance showed a significant effect $(P \leq 0.05)$ on concentrations of MgO NPs, MgO@C NPs and $\mathrm{Mg}\left(\mathrm{NO}_{3}\right)_{2}$ and seed germination (Fig. 2c, 2d and 2e). Seeds pretreated with concentration of $150 \mathrm{mg} \cdot \mathrm{L}^{-1} \mathrm{MgO}$ NPs showed an increase of $7.7 \%$, compared to the control. The seeds pretreated with MgO@C NPs, all concentrations showed a germination percentage higher than the control around $3 \%$. A reduction of $2.1 \%$ was observed in germination percentage of seeds treated with $\mathrm{Mg}\left(\mathrm{NO}_{3}\right)_{2}$, when compared to control.

The Figs. $2 \mathrm{~d}$ and $2 \mathrm{e}$ also shows the percentage of abnormal seedlings under effects of concentrations of MgO NPs, $\mathrm{MgO} @ \mathrm{C} N \mathrm{NPs}$ and $\mathrm{Mg}\left(\mathrm{NO}_{3}\right)_{2}$ during 90 or 150 days. We also observed high germination percentage of seeds treated with MgO@C NPs, stored for 150 days, compared to the seeds treated with $\mathrm{Mg}\left(\mathrm{NO}_{3}\right)_{2}$. There was a negative effect of $\mathrm{Mg}\left(\mathrm{NO}_{3}\right)_{2}$ on seed germination potential at 150 days storage due to increased concentration of this salt which concomitantly increased the abnormal seedlings percentage. Figs. $2 \mathrm{~d}$ and $2 \mathrm{e}$ show the best seed germination performance, as evidenced by the germination percentage, which can be considered an added benefit by the treatment process with MgO NPs and MgO@C NPs. However, for $\mathrm{Mg}\left(\mathrm{NO}_{3}\right)_{2}$, it seems that there may be a toxic effect due to the saline effect of this source. The results indicate an optimal Mg concentration value close to $75 \mathrm{mg} \cdot \mathrm{L}^{-1}$, in which it is possible to increase the germination percentage by approximately $6 \%$ due to use of NPs, whereas all concentrations were produced the germination values above to the control.

Regarding the performance of the seed treatment with $\mathrm{Mg}\left(\mathrm{NO}_{3}\right)_{2}$, the results of Figs. $2 \mathrm{~b}, 2 \mathrm{~d}$ and $2 \mathrm{e}$ indicate a negative saline effect of this salt on the performance of treated and stored seeds. This becomes worsen due to longer storage time of maize seeds, because the germination potential was decreased as function of higher salt concentration of this source with proportional increasing the abnormal seedlings percentage, respectively.

\section{Discussion}

Single or core-shell nanoparticles of $\mathrm{MgO}$ are adsorbed on fibrous cells in the seed pericarp and anchored as an agglomerate in the cell cavities. This characteristic, associated with storage time, favors the migration of $\mathrm{MgO}$ nanostructures to the seed endosperm, transforming agglomerates in viable reserves of magnesium for the seed, with availability throughout its development phases and germination process.

This result corroborates with Segatto et al. (2018), when the agglomerates are formed by nanostructures up to $50 \mathrm{~nm}$ size and much smaller than the surface cavity dimensions. These characteristics make possible the gradual migration of nanoparticles into the seed. The same authors reported that the process of incorporation of nanoparticles to layers below the pericarp should be slower, considering that it will occur by diffusion towards the pericarp into the seed. 
Table 1. Magnesium sources, equations models and equations adjusted, as MgO NPs (MgO) - triangle, MgO core-shell NPs (MgO@C) - square, and $\mathrm{Mg}\left(\mathrm{NO}_{3}\right)_{2}$ - circle.

\begin{tabular}{|c|c|c|c|}
\hline Figure & Magnesium source & Equation model & Equation adjusted \\
\hline Fig. 1 & $\begin{array}{l}\text { V MgO germination } \\
\Delta \mathrm{MgO} \text { abnormal seedlings } \\
\text { - MgO@C germination } \\
\square \mathrm{MgO} @ \mathrm{C} \text { abnormal seedlings } \\
\text { - } \mathrm{Mg}\left(\mathrm{NO}_{3}\right)_{2} \text { germination } \\
\circ \mathrm{Mg}\left(\mathrm{NO}_{3}\right)_{2} \text { abnormal seedlings }\end{array}$ & $\begin{array}{l}f=y 0+a^{*}\left(1-b^{\wedge} x\right) \\
f=y 0+a^{*} \exp \left(-b^{*} x\right) \\
f=y 0+a^{*}\left(1-b^{\wedge} x\right) \\
f=y 0+a^{*} \exp \left(-b^{*} x\right) \\
f=y 0+a^{*} \exp \left(-b^{*} x\right) \\
f=y 0+a^{*}\left(1-b^{\wedge} x\right)\end{array}$ & $\begin{array}{l}f=92.319+2.106^{*}\left(1-0.990^{\wedge} x\right) R^{2}=0.975 \\
f=-14.818+21.724^{*} \exp \left(-0.001^{*} x\right) R^{2}=0.92 \\
f=91.944+6.723^{*}\left(1-0.994^{\wedge} x\right) R^{2}=0.995 \\
f=6.501+0.502^{*} \exp \left(-1.001^{*} x\right) R^{2}=0.762 \\
f=84.006+8.311^{*} \exp \left(-0.011^{*} x\right) R^{2}=0.95 \\
f=7.684+8.311^{*}\left(1-0.989^{\wedge} x\right) R^{2}=0.951\end{array}$ \\
\hline Fig. 2a & $\begin{array}{l}\text { Mean of Mg sources: } \\
\downarrow \text { Germination } \\
\Delta \text { Abnormal seedlings }\end{array}$ & $\begin{array}{l}f=y 0+a^{*}\left(1-b^{\wedge} x\right) \\
f=y 0+a^{*} \exp \left(-b^{*} x\right)\end{array}$ & $\begin{array}{l}f=91.001+4.001 *\left(1-0.502^{\wedge} x\right) R^{2}=0.831 \\
f=5.548+3.459^{*} \exp \left(-0.071^{*} x\right) R^{2}=0.871\end{array}$ \\
\hline Fig. $2 b$ & $\begin{array}{l}\text { V MgO germination } \\
\Delta \mathrm{MgO} \text { abnormal seedlings } \\
\text { - MgO@C germination } \\
\square \mathrm{MgO} @ \mathrm{C} \text { abnormal seedlings } \\
\text { - } \mathrm{Mg}\left(\mathrm{NO}_{3}\right)_{2} \text { germination } \\
\circ \mathrm{Mg}\left(\mathrm{NO}_{3}\right)_{2} \text { abnormal seedlings }\end{array}$ & $\begin{array}{l}f=y 0+a^{*}\left(1-b^{\wedge} x\right) \\
f=y 0+a^{*} \exp \left(-b^{*} x\right) \\
f=y 0+a^{*}\left(1-b^{\wedge} x\right) \\
f=y 0+a^{*} \exp \left(-b^{*} x\right) \\
f=y 0+a^{*} \exp \left(-b^{*} x\right) \\
f=y 0+a^{*}\left(1-b^{\wedge} x\right)\end{array}$ & $\begin{array}{l}f=93.000+1.600^{*}\left(1-0.501^{\wedge} x\right) R^{2}=0.721 \\
f=4.947+2.028^{*} \exp \left(-0.013^{*} x\right) R^{2}=0.811 \\
f=91.020+4.002^{*}\left(1-0.513^{\wedge} x\right) R^{2}=0.924 \\
f=3.753+3.662^{*} \exp \left(-0.009^{*} x\right) R^{2}=0.631 \\
f=88.936+4.417^{*} \exp \left(-0.006^{*} x\right) R^{2}=0.874 \\
f=7.001+2.400^{*}\left(1-0.503^{\wedge} x\right) R^{2}=0.631\end{array}$ \\
\hline Fig. 2c & $\begin{array}{l}\nabla \mathrm{MgO} \text { germination } \\
\triangle \mathrm{MgO} \text { abnormal seedlings } \\
\text { - MgO@C germination } \\
\square \mathrm{MgO} @ \mathrm{C} \text { abnormal seedlings } \\
\text { - } \mathrm{Mg}\left(\mathrm{NO}_{3}\right)_{2} \text { germination } \\
\circ \mathrm{Mg}\left(\mathrm{NO}_{3}\right)_{2} \text { abnormal seedlings }\end{array}$ & $\begin{array}{l}f=y 0+a^{*}\left(1-b^{\wedge} x\right) \\
f=y 0+a^{*} \exp \left(-b^{*} x\right) \\
f=y 0+a^{*}\left(1-b^{\wedge} x\right) \\
f=y 0+a^{*} \exp \left(-b^{*} x\right) \\
f=y 0+a^{*} \exp \left(-b^{*} x\right) \\
f=y 0+a^{*}\left(1-b^{\wedge} x\right)\end{array}$ & $\begin{array}{l}f=91.040+5.002^{*}\left(1-0.511^{\wedge} x\right) R^{2}=0.893 \\
f=3.667+6.329^{*} \exp \left(-0.041^{*} x\right) R^{2}=0.811 \\
f=94.033+1.688^{*}\left(1-0.501^{\wedge} x\right) R^{2}=0.924 \\
f=3.947+2.028^{*} \exp \left(-0.013^{*} x\right) R^{2}=0.631 \\
f=88.073+2.964^{*} \exp \left(-0.047^{*} x\right) R^{2}=0.746 \\
f=9.021+2.801^{*}\left(1-0.504^{\wedge} x\right) R^{2}=0.761\end{array}$ \\
\hline Fig. 2d & $\begin{array}{l}\text { V MgO germination } \\
\Delta \mathrm{MgO} \text { abnormal seedlings } \\
\text { - MgO@C germination } \\
\square \mathrm{MgO} @ \mathrm{C} \text { abnormal seedlings } \\
\text { - } \mathrm{Mg}\left(\mathrm{NO}_{3}\right)_{2} \text { germination } \\
\circ \mathrm{Mg}\left(\mathrm{NO}_{3}\right)_{2} \text { abnormal seedlings }\end{array}$ & $\begin{array}{l}f=y 0+a^{*}\left(1-b^{\wedge} x\right) \\
f=y 0+a^{*} \exp \left(-b^{*} x\right) \\
f=y 0+a^{*}\left(1-b^{\wedge} x\right) \\
f=y 0+a^{*} \exp \left(-b^{*} x\right) \\
f=y 0+a^{*} \exp \left(-b^{*} x\right) \\
f=y 0+a^{*}\left(1-b^{\wedge} x\right)\end{array}$ & $\begin{array}{l}f=96.321+6.322^{*}\left(1-0.040^{\wedge} x\right) R^{2}=0.963 \\
f=3.491+1.561^{*} \exp \left(-0.149^{*} x\right) R^{2}=0.944 \\
f=94.621+1.602^{*}\left(1-0.505^{\wedge} x\right) R^{2}=0.924 \\
f=3.667+6.328^{*} \exp \left(-0.401^{*} x\right) R^{2}=0.631 \\
f=88.723+2.964^{*} \exp \left(-0.047^{*} x\right) R^{2}=0.757 \\
f=11.931+2.814^{*}\left(1-0.159^{\wedge} x\right) R^{2}=0.688\end{array}$ \\
\hline Fig. 2e & $\begin{array}{l}\nabla \mathrm{MgO} \text { germination } \\
\Delta \mathrm{MgO} \text { abnormal seedlings } \\
\text { - MgO@C germination } \\
\square \mathrm{MgO} @ \mathrm{C} \text { abnormal seedlings } \\
\text { - } \mathrm{Mg}\left(\mathrm{NO}_{3}\right)_{2} \text { germination } \\
\circ \mathrm{Mg}\left(\mathrm{NO}_{3}\right)_{2} \text { abnormal seedlings }\end{array}$ & $\begin{array}{l}f=y 0+a^{*}\left(1-b^{\wedge} x\right) \\
f=y 0+a^{*} \exp \left(-b^{*} x\right) \\
f=y 0+a^{*}\left(1-b^{\wedge} x\right) \\
f=y 0+a^{*} \exp \left(-b^{*} x\right) \\
f=y 0+a^{*} \exp \left(-b^{*} x\right) \\
f=y 0+a^{*}\left(1-b^{\wedge} x\right)\end{array}$ & $\begin{array}{l}f=95.402+3.982^{*}\left(1-0.060^{\wedge} x\right) R^{2}=0.774 \\
f=3.081+3.463^{*} \exp \left(-0.001^{*} x\right) R^{2}=0.971 \\
f=97.483+4.593^{*}\left(1-1.515^{\wedge} x\right) R^{2}=0.891 \\
f=2.452+5.813^{*} \exp \left(-0.551^{*} x\right) R^{2}=0.902 \\
f=86.782+2.221^{*} \exp \left(-0.088^{*} x\right) R^{2}=0.718 \\
f=13.201+4.201^{*}\left(1-0.505^{\wedge} x\right) R^{2}=0.607\end{array}$ \\
\hline
\end{tabular}

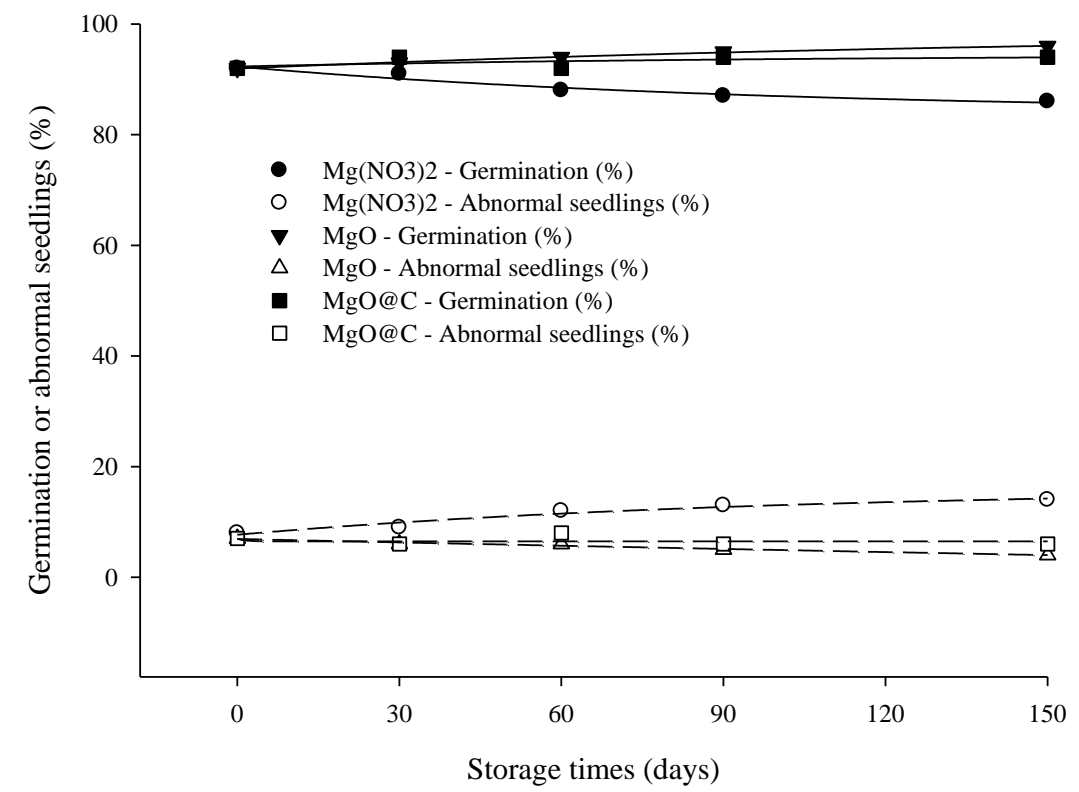

Fig 1. Effects of storage time on maize seed germination (close/black symbols; continuous lines) or abnormal seedlings (open/white symbols; dashed lines) in function of magnesium sources [MgO NPs (MgO) - square, MgO core-shell NPs (MgO@C) - circle, and $\mathrm{Mg}\left(\mathrm{NO}_{3}\right)_{2}$ - triangle]. 
a) 0 day of storage

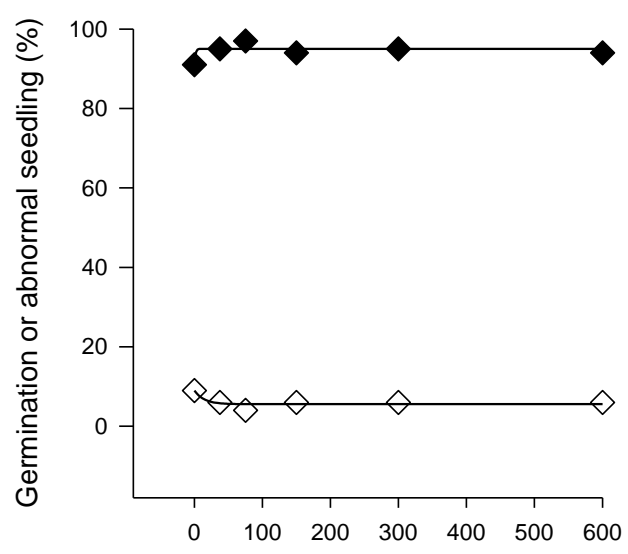

Mg concentration (mg. $\mathrm{L}^{-1}$ )

c) 60 days of storage

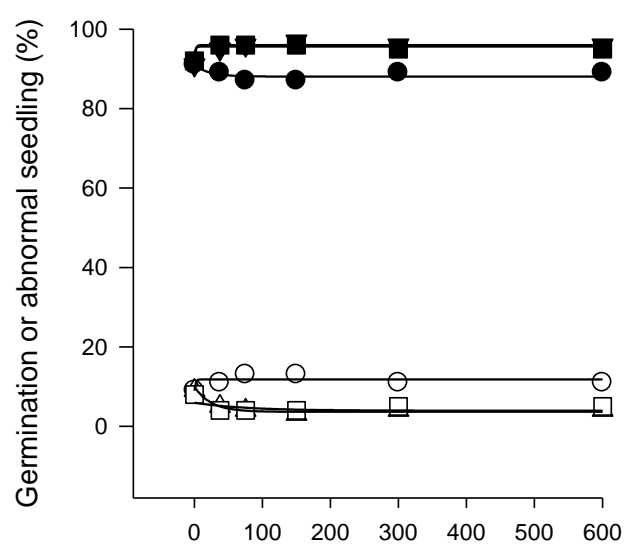

Mg concentration (mg. $\mathrm{L}^{-1}$ )

c) 150 days of storage

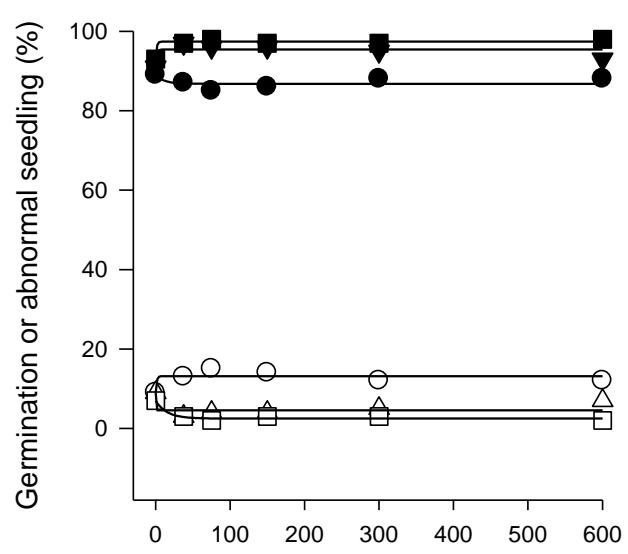

Mg concentration (mg. $\mathrm{L}^{-1}$ )

Fig 2. Effects of magnesium concentrations on maize seed germination (black symbols) and abnormal seedlings (white symbols) in function of sources [MgO NPs (MgO) - triangle, $\mathrm{MgO}$ core-shell NPs (MgO@C) - square, and $\mathrm{Mg}\left(\mathrm{NO}_{3}\right)_{2}$ - circle] and storage times: 0 day (a), 30 days (b), 60 days (c), 90 days (d) and 150 days (e).

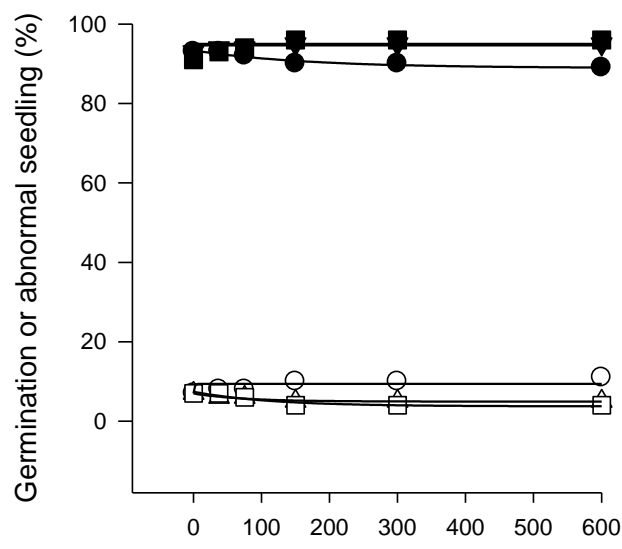

Mg concentration (mg. $\left.\mathrm{L}^{-1}\right)$

d) 90 days of storage

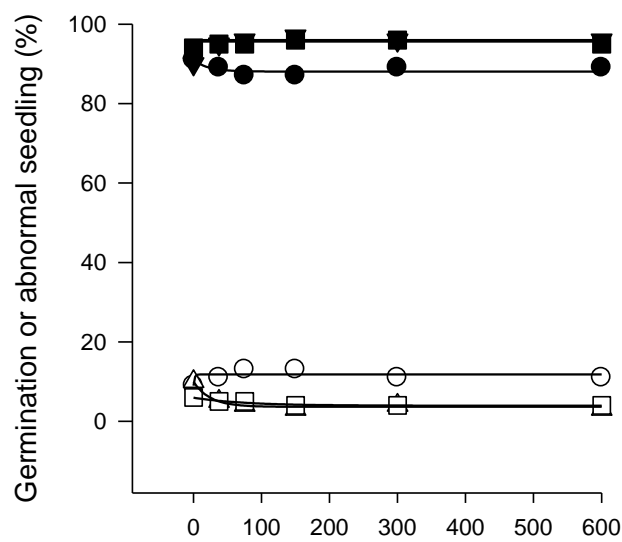

Mg concentration (mg. $\left.\mathrm{L}^{-1}\right)$ 
Over a long period of storage, the migration of zinc oxide nanoparticles from the agglomerates into the seed is occurred, considering that the agglomerates are formed by zinc oxide particles smaller than $100 \mathrm{~nm}$ and the interface pores between pericarp cells have 1 to $2 \mu \mathrm{m}$ (Segatto et al., 2018). In such a way, the results of Figs $2 d$ and 2 e suggest the need for a longer storage time of seeds submitted to treatment only with MgO NPs and MgO@C NPs to maintain germinability of maize seeds.

De La Rosa et al. (2013) reported up to $10 \%$ increase in cucumber seed germination exposed to $1,600 \mathrm{mg} \cdot \mathrm{L}^{-1} \mathrm{ZnO}$ NPs. However, a reduction by 40 and $20 \%$ was observed in seed germination of alfalfa and tomato, respectively. Siddiqui and Al-Whaibi (2014) revealed that the application of $\mathrm{SiO}_{2} \mathrm{NPs}$ significantly increased tomato seed germination. The wheat (Triticum aestivum) seeds treated with graphene oxide NPs showed a decrease in germination rate (Vochita et al., 2019).

Feizi et al. (2013) observed that the exposure of wheat seed to $100 \mathrm{mg} \cdot \mathrm{L}^{-1}$ iron oxide nanoparticles provided the highest germination rate, increasing the germination rate by $41 \%$ compared to the control.

According to Jayarambabu et al. (2016) the synthesized MgO NPs stimulated the germination of maize seeds, and the results showed that the highest and lowest germination percentage $(95 \%$ and $80 \%)$ were obtained in the concentration of $100 \mathrm{mg} \mathrm{MgO} \mathrm{NPs}$ and the control, respectively. Results with germination test indicated that the final germination percentage was significantly affected by the treatment. However, the increase in MgO NPs concentration up to $150 \mathrm{mg}$ provided an increase in seed germination and after that decreased (Jayarambabu et al., 2016). Results of Segatto et al. (2018) using concentrations of ZnO NPs near $50 \mathrm{mg} . \mathrm{L}^{-1}$, indicates an increase of approximately $3 \%$ in the number of normal maize seedlings. The seed treatment of Lupinus termis L. with $100 \mathrm{mg} . \mathrm{L}^{-1}$ silver nanoparticle concentrations improves the germination and growth. However, it indicated that exposure to high concentrations of NPs (300 and $500 \mathrm{mg} . \mathrm{L}^{-1}$ ) resulted in a highly significant reduction in all growth parameters (AlHuqail et al., 2018).

Lee et al. (2010) observed that about 94\% of Arabidopsis thaliana seeds did not germinate at a concentration of 400 mg. $L^{-1} \mathrm{ZnO} N P s$, and the exposure of seeds to $\mathrm{Zn}$, added with $\mathrm{Zn} \mathrm{Cl} 2$, caused phytotoxicity from the concentration of 250 $\mathrm{mg} \cdot \mathrm{L}^{-1}$. Corroborating the results of Segatto et al. (2018) in using ZnO NPs concentrations greater than $240 \mathrm{mg} \cdot \mathrm{L}^{-1}$, the effect was negative and the percentage of normal seedlings was reduced. It is likely that the negative effects of NPs concentrations greater than $240 \mathrm{mg} \cdot \mathrm{L}^{-1}$ are associated with damage caused in plant cells due to excess zinc.

Other external factors may affect the performance of NPs on Seeds. For example, Lópes-Moreno et al. (2017) showed that room temperature can modify the effects of exposure of ZnO NPs on seeds. In addition, there is also interaction between NPs concentrations and temperature, since at $20^{\circ} \mathrm{C}$ there was a significantly reduce in seed germination under exposure to 400 and $1.600 \mathrm{mg} . \mathrm{L}^{-1}$, while at $25^{\circ} \mathrm{C}$, only 400 $\mathrm{mg} \cdot \mathrm{L}^{-1}$ caused negative effect.

This germination increase may also be related to the protection of nanoparticles in maize seeds. Wani and Shah (2012) observed that $\mathrm{ZnO}$ and $\mathrm{MgO}$ nanoparticles at different concentrations cause significant inhibition of spore's germination of Alternaria alternata, Fusarium oxysporum and Rhizopus stolonifer. Higher concentration of
MgO nanoparticles was found to be more effective in reducing spore germination, followed by $\mathrm{ZnO}$ nanoparticles at the same concentration.

In addition, the results taken together suggest that concentrations of 75 and $150 \mathrm{mg} . \mathrm{L}^{-1} \mathrm{NPs}$ associated with 3060 days storage time are favorable to improve the germination performance of maize seeds. No clear difference was observed between MgO NPs and MgO@C NPs, as both were favorable in case of seed pretreatments associated with longer storage time (90-150 days). This is one of the first scientific research papers to use synthetic magnesium nanoparticles on the germination performance of corn seeds. It is also a promising tool for maintaining the physiological quality of (high seed quality) seeds of this species for long periods of storage.

\section{Materials and Methods}

\section{Maize seeds and nanoparticles}

The experiment was carried out in the Crop Plant Laboratory at the Agroveterinary Sciences Center of the Santa Catarina State University (CAV/Udesc), in Lages, Santa Catarina, Brazil. The maize seeds used in this research, named P4285HYR, were supplied by the Pioneer Company, containing the Optimum ${ }^{\circledR}$ Intrasect ${ }^{\circledR}$ technology. The seeds are classified by the cultivar breeder as a simple, high-tech hybrid for cultivation with a population around 60,000 plants per hectare (Pioneer, 2018).

The magnesium oxide nanoparticles and the magnesium oxide and carbon core - shell structures were provided by the Multifunctional Materials Laboratory of the Chapecó Region Community University - Unochapecó. Particles showed $25 \mathrm{~nm}$ average size and $99.5 \%$ purity. Magnesium nitrate showed $98.0 \%$ purity (Vetec, PA standard).

\section{Seed treatment and storage conditions}

Maize seed treatments were carried out in open glass reactors (becker type), using distilled water at room temperature as diluent, and then stirred in a plastic bag containing different concentrations and different magnesium precursors. After the treatment processes, the seeds were placed in paper bags, identified according to the respective treatments and concentrations, and stored in a dry chamber with $50 \pm 5 \%$ relative humidity and $8 \pm 4$ oC temperature until the further germination tests.

\section{Germination test}

The experimental conditions were established using the type of sources of magnesium [MgO NPs, MgO@C NPs and $\left.\mathrm{Mg}\left(\mathrm{NO}_{3}\right)_{2}\right]$ as factor "a" and the concentrations of each source of magnesium [0 (control, only water), 37.5, 75, 150, 300 and $600 \mathrm{mg} \cdot \mathrm{L}^{-1}$ ] as factor " $\mathrm{b}$ ".

After the treatments, the seeds were submitted to germination tests, carried out from December 2016 to June 2017, with different storage times in a dry chamber: 0,30 , 60,90 , and 150 days of storage, as factor " $c$ ". The experimental design was completely randomized, arranged in a $3 \times 6 \times 5$ factorial scheme with four replications for each experimental condition.

Seed germination tests were performed on special paper germination substrates (Germitest ${ }^{\circledR}$ ), moistened with a solution volume equivalent to 2.5 times its weight. For each 
roll made, three sheets of paper towels were used. Germination tests were conducted with four sub-samples of 50 seeds for each treatment, according to the criteria established in the Brazilian Seed Analysis Rules (Brasil, 2009). The rolls were placed in a germinating chamber (Mangelsdorf model) regulated to maintain a constant temperature of $25 \pm 2 \stackrel{\circ}{ } \mathrm{C}$.

The germination (first count) was evaluated on the fourth day after the test installation. The final germination (second count) was obtained by summing the first and second count, which performed on the seventh day after the test installation. Data were converted to germination or abnormal seedlings percentage (Brasil, 2009).

\section{Statistical method}

Data were subjected to analysis of variance by the $F$ test $(P \leq 0.05)$. When significant difference observed (qualitative factor), the means were compared by Scott-Knott test at 5\% probability. For the factor concentrations (quantitative factor), data were submitted to regression adjustment by nonlinear models (Table 1). Analysis were performed using Sisvar (Ferreira, 2014) and Sigmaplot softwares.

\section{Conclusion}

A better germination performance of seeds pretreated with MgO NPs and MgO@C NPs can be considered a benefit aggregated by the seed pretreatment process in combination with both concentrations and storage time. These both Mg NPs sources showed the better potential results around concentration of $75 \mathrm{mg} \cdot \mathrm{L}^{-1}$; maintaining high germination potential per long time, at least five months after seed treatments.

\section{Acknowledgements}

The authors would like to thank CNPq, CAPES, FAPESC/UDESC/PAP and UNIEDU for their financial support to the present research and the scholarships granted to the authors.

\section{Conflict of Interest}

The authors declared that there is no conflict of interest.

\section{References}

Aguar-Fernandez MP, Hullmann A (2007) A boost for safer nanotechnology. Nano Today. 2(1): 56-56.

Al-Huqail AA, Hatata MM, Al-Huqail AA, Ibrahim MM (2018) Preparation, characterization of silver phyto nanoparticles and their impact on growth potential of Lupinus termis $\mathrm{L}$. seedlings. Saudi J Biol Sci. 25 (2): 313-319.

Brasil (2009) Ministério da Agricultura, Pecuária e Abastecimento. 2009. Regras para análise de sementes. Brasília: MAPA. 398p.

Brasil (2013) Instrução Normativa no 45, de 17 de setembro de 2013 (estabelece normas específicas e padrões de identidade e qualidade para a produção e comercialização de diversas sementes). Diário Oficial da União: Brasília, de 20 de setembro de 2013. Seção 1, 6p.

Cakmak I, Yazici AM (2010) Magnesium: a forgotten element in crop production. Better Crops. 94: 23-25.

Chhipa HJ (2019) Applications of nanotechnology in agriculture. Method Microbiol. 46: 115-142.

CQFS-RS/SC - Comissão de química e fertilidade do solo RS/SC (2016) Manual de adubação e calagem para os
Estados do Rio Grande do Sul e de Santa Catarina. 11 ed. Porto Alegre: SBCS - Núcleo Regional Sul/UFRGS. 376p.

De La Rosa G, López-Moreno ML, Haro D, Botez CE, PeraltaVidea JR, Gardea-Torresdey JL (2013) Effects of ZnO nanoparticles in alfalfa, tomato, and cucumber at the germination stage: Root development and X-ray absorption spectroscopy studies. Pure Appl Chem. 85: 2161-2174.

Feizi H, Moghaddam PR, Shahtahmassebi N, Fotovat A (2013) Assessment of concentrations of nano and bulk iron oxide particles on early growth of wheat (Triticum aestivum L.) Annu Rev Res Biol. 3: 752-761.

Ferreira DF (2014) Sisvar: a Guide for its Bootstrap procedures in multiple comparisons Ciênc Agrotec. 38: 109-112.

FAO (2019) FAOSTAT. Food and Agriculture Organization of the United Nations. Available at: http://faostat.fao.org/faostat. Accessed october 10, 2019.

Gout E, Rébeillé F, Douce R, Bligny R (2014) Interplay of $\mathrm{Mg}^{2+}, \mathrm{ADP}$, and ATP in the cytosol and mitochondria: unravelling the role of $\mathrm{Mg}^{2+}$ in cell respiration. Proc Natl Acad Sci. 111(43): 4560-4567.

Gransee A, Führs H (2013) Magnesium mobility in soils as a challenge for soil and plant analysis, magnesium fertilization and root uptake under adverse growth conditions. Plant Soil 368: 5-21.

Jayarambabu N, Siva K, Venkateswara RK, Prabhu YT (2016) Enhancement of growth in maize by biogenic- synthesized MgO nanoparticles. Int J Pure Appl Zool. 4: 262-270.

Lee CW, Mahendra S, Zodrow K, Li D, Tsai YC, Braam J, Alvarez PJ (2010) Developmental phytotoxicity of metal oxide nanoparticles to Arabidopsis thaliana. Environ Toxicol Chem. 29: 669-675.

Liu R, Zhang H, Lal R (2016) Effects of stabilized nanoparticles of copper, zinc, manganese, and iron oxides in low concentrations on lettuce (Lactuca sativa) seed germination: nanotoxicants or nanonutrients? Water Air Soil Poll. 227: 42-42.

Lopez-Moreno ML, Rosa GD, Cruz-Jiménez G, Castellano LA, Peralta-Videa, JR, Gardea-Torresdey JL (2017) Effect of ZnO nanoparticles on corn seedlings at different temperatures; X-ray absorption spectroscopy and ICP/OES studies. Microchem J. 134: 54-61.

Pioneer (2018) Pioneer Sementes de Milho. DuPont Pioneer. Available at: http://www.pioneersementes.com.br/milho (Accessed august 26, 2019)

Segatto C, Ternus R, Junges M, Mello JMM, Luz JL, Riella RG, Silva LL, Lajús CR, Fiori MA (2018) Adsorption and incorporation of the zinc oxide nanoparticles in seeds of corn: germination performance and antimicrobial protection. J IJAERS. 5: 2456-6495.

Siddiqui MH, Al-Whaibi MH (2014) Role of nano-SiO2 in germination of tomato (Lycopersicum esculentum seeds Mill.). Saudi J Biol Sci. 21 (1): 13-17.

Tarafdar JC, Sharma S, Raliya R (2013) Nanotechnology: interdisciplinary science of applications. Afr J Biotechnol. 12 (3): 219-226.

Vochita G, Oprica L, Gherghela D, Mihai C-T, Boukherroub R, Lobiuc A (2019) Graphene oxide effects in early ontogenetic stages of Triticum aestivum L. seedlings. Ecotox Environ Safe. 181: 345-352.

Wani AH, Shah MA (2012) A unique and profound effect of $\mathrm{MgO}$ and $\mathrm{ZnO}$ nanoparticles on some plant pathogenic fungi. J Appl Pharm Sci. 2 (3): 40-44. 